\title{
The corporate uses of debt
}

\author{
Sinclair Davidson \& Laurence Rapp \\ Department of Business Economics, School of Economic and Business Studies, University of the Witwatersrand, \\ Private Bag 3, P.O. Wits, 2050 Republic of South Africa and Monitor Company ${ }^{1}$
}

Received February 1995

\begin{abstract}
In this article we consider the use of debt by South African firms. There are two possible uses of debt: firstly, it is a method of raising finance and secondly, a method of corporate governance. Within the South African corporate environment it is not clear whether firms would use debt for both or either of these purposes. We are unable to find evidence in favour of Modigliani and Miller's proposition one or proposition two. It appears that firms do not use debt for corporate governance purposes and we present evidence that there could be an agency problem inherent within the structure of South African business.
\end{abstract}

In hierdie artikel bestudeer ons die gebruik van skuld deur Suid-Afrikaanse maatskappye. Daar is twee moontlike funksies vir die gebruik van skuld; eerstens is dit 'n metode om finansiering te bekom, en tweedens is dit 'n manier om die verhoudings tussen aandeelhouers en bestuur te reguleer. Dit is nie duidelik of Suid-Afrikaanse maatskappye skuld vir een of beide van hierdie doeleindes aanwend nie. Ons het geen bewyse vir Modigliani en Miller se eerste stelling of vir hulle tweede stelling nie. Dit blyk dat maatskappye nie skuld gebruik as 'n manier om die verhoudings tussen aandeelhouers en bestuur te reguleer nie. Ons bewys dat daar ' $n$ inherente agentskapsprobleem binne die Suid-Afrikaanse sakestruktuur bestaan.

\section{Corporate uses of debt}

The existence of an optimal capital structure is both one of the most complex and important issues in corporate finance. This topic has been hotly debated since the late 1950 s. Since then financial economists have investigated the issue of capital structure, yet seem to be no closer to a general conclusion on the subject. Indeed, Myers (1993: 142) has argued that the search for optimal capital structure is like the search for truth or wisdom. Either goal is elusive.

Debt can have two uses. It can be used as a method of raising finance. In addition, it can take on corporate governance aspects, where management take on debt to 'bond' themselves to equity providers of the firm (see Jensen \& Meckling, 1976). Within the South African corporate environment, it is not clear whether firms would use debt for both or either of these purposes. The analysis of the South African environment is particularly interesting as the dominant institutional structure of ownership is very different from that of, say, the United States of America (where most research in this field is conducted).

In this article we investigate the impact of debt on the operating performance of the firm and by implication on the firm's market value. In addition, we investigate whether or not debt is used as a governance structure in the South African corporate environment. This entails examining some of the determinants of ownership that have been hypothesized by Demsetz \& Lehn (1985). An agency problem related to the structure of ownership in South Africa is hypothesized.

In the first three sections of this article, we develop the necessary theoretical constructs. The fourth section contains our method and a discussion of results. A conclusion follows.

\section{Irrelevance of debt}

Modigliani \& Miller (1958) demonstrated that in perfect capital markets capital structure did not matter. Their first proposition (MMI) is that the 'market value of any firm is independent of its capital structure' (Modigliani \& Miller, 1958: 156) and the second (MMII), based upon the first, states that 'the expected yield of a share of stock is equal to the appropriate capitalization rate ... plus a premium related to financial risk' (Modigliani \& Miller, 1958: 158). The managerial implication of these statements is that managers should concentrate on creating wealth through investments and not through adjusting the firm's capital structure. While these propositions have earned Modigliani \& Miller the Nobel prize in economics, Jensen (1993: 45) has argued that their propositions have no empirical validity. The logic and proofs of the Modigliani \& Miller position are irreproachable and if it seems that if their propositions are false, then it is because they have ignored or assumed away some factor(s).

Miller (1988: 130) has argued that in order to understand the Modigliani \& Miller propositions, we must invert the reasoning: by understanding what does not matter, by implication we know what does. The three core assumptions to the propositions are no taxes, no transaction costs and no market imperfections. It is by examining these three areas that it becomes possible to find instances where capital structure can matter.

Modigliani \& Miller (1963) demonstrated that when corporate taxes are added to the debate a 'corner solution' arises. The value of the firm is equal to the sum of the equity value plus the present value of a tax shield. This tax shield is created through the tax implications of debt financing vis-a-vis equity finance. This model predicts that firms should hold $100 \%$ of its value as debt. Not only is this impractical, but it does not exist in practice. As it is unlikely that managers have not realized the advantages of debt, there must be some counterbalancing force that makes the corner solution not viable. Stiglitz (1969: 429) has suggested that (positive) bankruptcy costs modify the position. This leads us to the so-called static tradeoff theory. The advantages of corporate debt lead the firm to take on more and more debt, while the expected costs of bankruptcy create an upper limit to the amount of debt that the firm will eventually hold. 
Miller (1976) has modified the tradeoff theory by adding personal taxation to the analysis. This has the effect of modifying the tax shield. By assuming that there are two types of personal taxes, namely one related to earning income from equity $\left(T_{e}\right)$ and another associated with income from debt $\left(T_{0}\right)$, it can be shown that the tax shield associated with corporate debt is (Copeland \& Weston, 1988: 452):

$$
\text { Taxshield }=\left(1-\frac{\left(1-T_{c}\right)\left(1-T_{e}\right)}{\left(1-T_{d}\right)}\right) D
$$

where:

$T_{c}=$ the nominal corporate tax rate; and,

$\mathrm{D}=$ the market value of corporate debt.

The expression (.) indicates the relative advantage to debt financing. A firm that is attempting to maximize the after-tax wealth of its shareholders may take (1) into account when using debt in its capital structure.

There is some controversy as to the empirical validity of the static tradeoff theory. Warner (1977: 66) argues that the direct costs of bankruptcy are only $1 \%$ of market value prior to bankruptcy. Altman (1984: 1087) finds that the direct and indirect costs of bankruptcy vary between 11 and $17 \%$ of market value three years prior to bankruptcy. The Altman (1984) study is clearly superior, as it considers both the direct costs and the opportunity cost of bankruptcy.

By relaxing two of the crucial assumptions (no taxes and no transaction costs) underlying the Modigliani \& Miller propositions, it is possible to draw the conclusion that managers should pay some attention to the capital structure decision. Capital structure may become important if managers are able to exploit taxes (the creation of tax shields) or (lower) transaction costs. Indeed, Miller (1992: 343) states that many of the financial innovations of the past twenty years are taxinduced. A relaxation of the third assumption, namely no market imperfections, introduces the realm of agency theory.

\section{Agency aspects of debt}

The agency problem arises out of the (alleged) separation of ownership and control. Jensen (1989: 61) characterizes the agency problem as being a dispute between owners and managers over the control and use of resources. The pay out of 'free cash flow' (cash in excess of that required to finance all positive net present value transactions available to the firm) is at the centre of the agency problem (Jensen, 1986: 323). Donaldson (1984: 22) has argued that managers wish to maximize corporate wealth, the aggregate purchasing power available to management, even if this entails investing in negative net present value activities.

For this problem to persist, managers must be able to circumvent at least five market constraints (the control hierarchy):

- shareholder control;

- the product market;

- the market for managers;

- the market for new finance; and,

- the market for corporate control (Santerre \& Neun, 1993: 466-467).

Jensen (1993: 3) argues that internal control mechanisms have largely been ineffectual in constraining management.
Similarly, the product market and the market for new finance generate large and unnecessary costs (associated with the length of time that it takes for these markets to operate). The United States corporate control market was very active in the 1980s, probably for these reasons.

Jensen (1986: 323) argues that a way to 'activate' internal markets and control mechanisms is to find methods that motivate managers to pay out free cash instead of reinvesting in non-profitable projects. He argues further that an increase in dividends (containing the implicit promise to maintain the increase) is not credible as dividends can be reduced at the management's pleasure. The use of debt is a credible promise to pay out free cash flow (Jensen, 1986: 324). Debt thus serves as a check against managerial indiscretion. Debt becomes more than a financing tool; it takes on aspects of a governance structure (Williamson, 1988: 579). In fact, the issues of capital structure and corporate control should not, and indeed cannot, be separated. Jensen (1989: 72) concludes that gearing up leads to better performance and resolves the conflict over free cash flow.

By ensuring that managers pay out any excess cash, the use of debt requires the managers to run the corporation in the interests of the shareholders. Given high levels of debt, the managers cannot retain funds at their discretion. If they fail to make the promised debt payments the debt holders can force payment through the bankruptcy courts. This brings the market for managers into play. In addition, should the firm require additional funds, it will need to resort to the market for new finance. If agency problems are rife, it will be unable to raise finance on favourable terms. These firms will also become vulnerable to the discipline of the product market, as it fails to keep abreast of economic and technological change. All these sentiments can be summed up in the following statement from Stewart \& Glassman (1988: 602): 'Equity is soft, debt hard. Equity is forgiving, debt insistent. Equity is a pillow, debt a sword'.

While increased leverage reduces the agency problem, the question of bankruptcy arises. In addition, the potential for conflict between management, shareholders and bondholders also arises. Jensen (1986: 324) thus defines the optimal capital structure as one where the marginal cost of debt is equal to the marginal benefit of debt. This is an extension of the static tradeoff theory.

\section{South African business and the agency problem}

Gerson (1992) and Gerson \& Barr (1992) have undertaken an extensive study into ownership and control in South Africa. The South African economy is characterized by pyramid structures which have the effect of separating ownership and control. Pyramid structures allow (minority) shareholders to maintain absolute control of the firm, with a small equity stake. This allows owner-managers to diversify their wealth and/or expand their business, while maintaining control over the firm.

It can be seen that the dominant mode of ownership is very different from that of the United States. In that country, pyramids are not dominant nor are firms generally controlled by such shareholders. Denis \& Denis (1994: 93) investigate the relative efficiency of such firms and state that, ' $(t)$ he factors that make majority ownership a viable ownership structure 
for some firms remain unclear' (emphasis added). The reason for their apparent puzzlement is the potential agency problems associated with such a structure. Denis \& Denis (1994: 92) write that, '(e)ven with substantial ownership of cash flow rights, managers have incentives to take actions that benefit themselves at the expense of other shareholders'. Demsetz (1986: 224) argues that owner-managers maintain their position because they have, or believe that they have, a comparative advantage in control and this advantage is worth utilizing to realize pecuniary and non-pecuniary returns'. In the South African firm, the same incentive should be apparent. Within the South African firm, however, the owner-manager does not own the majority of cash flow rights and does not bear the full financial consequences of his actions. In order for the pyramid structure to be efficient, the improvements in monitoring must exceed the cost of the decreased claim on cash flow. In addition, some credible signal must exist that convinces investors of the owner-manager's bona fides.

Gerson \& Barr (1992: 7) argue that within pyramids management is subject to strong shareholder control and this by implication alleviates the agency problem. Unless the ownermanager is able to convince 'outside' investors of his ability to manage the firm completely and offer them reasonable return, he will be unable to form the pyramid. This ability to convince outsiders (signal), Gerson \& Barr (1992: 4) label 'reputation', i.e. the ability to motivate and monitor management, resulting in good corporate performance. The central testable hypothesis of their paper is that the greater the reputation of the entrepreneur, the smaller his equity stake in the pyramid (Gerson \& Barr, 1992:5).

Gerson \& Barr (1992: 18) attempt to substantiate their hypothesis using wealth and price-earnings (PE) ratios as a proxy for reputation. They also argue that firms with wealthy owner-managers (i.e. personal wealth greater than R200 million) have higher $\mathrm{PE}$ ratios and higher growth rates in $\mathrm{PE}$ ratios than firms with less wealthy owner-managers. Gerson \& Barr (1992) correctly point out that there are several shortcomings in their use of proxies. In addition to their self-criticism, we must add that due to the positive transaction costs associated with forming pyramids, it stands to reason that wealthier investors will be able to pyramid i.e. they pyramid because they can. We expect a negative relationship between wealth and equity stake in a pyramid. The analysis with PE ratios is also unconvincing. There is a survivor bias in the study. It is possible that high $\mathrm{PE}$ ratios could have arisen from the nature of the firms concerned. Again, we expect that wealthy individuals would tend to own successful enterprises and control the 'commanding heights' of the economy. The causation between ownership and PE ratios is not necessarily that implied by Gerson \& Barr (1992).

The analysis begs the question, 'why does equity prevail over debt?'. Indeed, Gerson \& Barr (1992: 4 and 8) seem to avoid the issue of debt. If the motive is simply to expand the operation of the business and the owner-manager wishes to maintain control, why not simply issue debt? If one has a sufficient reputation to raise equity finance, surely that reputation is sufficient to raise debt. The argument that this does not allow the entrepreneur to diversify his holdings is fallacious. There is little to stop him from investing in a diversified port- folio on the market, entirely separate from his corporate activities. Three possible solutions present themselves. Firstly, the existence of prescribed asset requirements may have stifled a corporate debt market in South Africa. Secondly, debt is hard and unforgiving. Thirdly, the Gerson \& Barr (1992) analysis seems to ignore the potentially adverse effects of exchange control.

Gerson (1992:76) argues that there are countervailing considerations to debt in an environment characterized by pyramids. As regards agency problems, Gerson \& Barr (1992) imply that dominant shareholders substitute for debt and so firms should have lower debt-equity ratios. On the other hand, firms within pyramids have lower risk of bankruptcy and should be able to attract debt finance at attractive rates. As such, firms in a pyramid environment should have higher debt-equity ratios. This is due to the potential for cross subsidies, something which is inefficient in and of itself. It is not clear within the Gerson \& Barr (1992) framework which of these considerations dominate.

Gerson \& Barr's (1992) empirical results suggest prima facie that the performance of pyramid companies is superior to that of non-pyramid companies. Even if we accept this as true, it does not immediately follow that these structures are the most efficient form of organisation in South Africa. It merely supports the generally accepted hypothesis that the presence of a dominant (or activist) shareholder is crucial in generating superior performance. If, on the other hand, dominant shareholders can only express themselves through pyramids, their superior corporate performance and pyramid structures are compatible.

At this point it is instructive to examine the determinants of ownership as hypothesized by Demsetz \& Lehn (1985: 203207). They argue that there are four such determinants. There should be an inverse relationship between the optimal value maximizing size of the firm and the ownership stake. In South Africa, the pyramid structure overcomes this problem. We might expect the larger the firm, the more layers of pyramid that the owner-manager has, or would like to have. If we view the pyramid as a single entity, then the owner-manager would not necessarily hold a large stake in any one firm, but would hold a large stake in the pyramid as a whole (perhaps his stake would be inverse to the size of the pyramid). This implies that the owner-manager would not necessarily be interested in maximizing the value of any one firm, but would be interested in maximizing the value of the pyramid as a whole (we return to this point). It must be borne in mind, in the presence of positive information costs, that many layers in the pyramid can lead to organizational inefficiency.

Control potential refers to the wealth gain that can be achieved through effective monitoring. The 'noisier a firm's environment' the greater the demand for control (see Demsetz \& Lehn, 1985: 206). Noise in this context can be measured by variation in profitability or market share.

Regulation is a form of subsidized monitoring that is traded off against reduced profitable behaviour. As regulation is exogenous to the firm, we will not consider its effect in the remainder of the article. We do recognize however that the 
regulatory environment can and does affect ownership substantially, e.g. exchange control and prescribed asset requirements. The effects of these factors are beyond the scope of this article.

Amenity potential is the ability to consume on the job. Those industries where amenity potential is high can be expected to be characterized by tight control. If the ownermanager is not interested in any individual firm in the pyramid per se but in the pyramid as whole, then there is a prima facie case for amenity potential in South Africa. Demsetz \& Lehn (1985: 208) write that, '(w)e believe that there is nonpecuniary income associated with the provision of general leadership and with the ability to deploy resources to suit one's personal preferences' (emphasis added). In the absence of takeover markets there is nothing to stop the owner-manager from availing himself of this form of non-pecuniary income. As an aside, company law does not recognize pyramids. Its point of analysis is the individual firm. To the extent that individual firms' interests are sacrificed for the greater good of the pyramid, the owner-mamger is in violation of the law.

If equity does prevail over debt, the solution must lie in one of the above reasons.

\section{Method and discussion of results}

Following from MMII there should be a positive relationship between rates of return and $\mathrm{D} / \mathrm{E}$ ratios. If tight control is a substitute for debt, there should be a negative relationship between control and D/E ratios. If the Gerson \& Barr (1992) model accurately captures the South African corporate environment, there should be a positive relationship between control and performance (for a counter view, see below). Finally, we also test for evidence of a conflict between ownermanagers and outsider shareholders.

In order to determine the impact of debt (and ownership) within the South African environment, relationships between ownership of the firms resources, its debt-equity (D/E) structure and various measures of performance were investigated.

The data used in the analysis was compiled from various sources: accounting and ownership data was drawn from McGregor (1992), while share price data was taken from INet. 1991 was chosen as the test period. The Finance Week 200 was originally chosen as the population. From this population all those companies that did not have a full set of financial statements in McGregor (1992) were eliminated, as were all non-industrial companies. This left a final total of seventy companies for analysis (see Appendix 1). For each company the following information was complied:

- equity percentage held by the top three shareholders;

- D/E ratio (market value) for 1991;

- return on assets (accounting) $\left(r_{2}\right)$ for the period 1989 1991;

- return on shareholder equity (accounting) $\left(r_{e}\right)$ for the period 1989-1991;

- earnings per share (EPS) for the period 1989-1991;

- dividend payout ratio (div.pay) for the period 1989-1991; and

- total monthly market returns for the period 1989-1991 (used to calculate $\beta$ 's). The (average) monthly market returns for 1991 were used in the analysis (mar-ret).
The three year data, in each case were used to calculate standard deviations. (See Table 1 for summary statistics).

According to the Modigliani \& Miller propositions, debt is irrelevant. If this is so there should be no relationship between $\mathrm{D} / \mathrm{E}$ ratios and various measures of performance. In order to test this hypothesis regressions between the $\mathrm{D} / \mathrm{E}$ ratio and the various measures of performance were run (see Table 2).

There seems to be no relationship between the return on equity and the $\mathrm{D} / \mathrm{E}$ ratio. There is a statistically significant negative relationship with return on assets and market returns. We cannot conclude that there is no relationship between the value of the firm and the financial structure of the firm. Unfortunately, MMII is not empirically valid. We would expect to find a positive relationship between $\mathrm{D} / \mathrm{E}$ and the two measures of return. This, however, is not so. It is possible that such a relationship between return and financial structure does exist, but is being swamped by other factors, such as the firms not being in 'equivalent risk classes'.

To take risk into account, it is necessary to develop measures that capture the operating and the financial risk of the firm. For this purpose we use the capital asset pricing model (CAPM). At the time when the Modigliani \& Miller theories were being developed, there was no accepted theory that allowed for differences in risk. This led to Modigliani \& Miller (1958: 154) referring to a vague concept of 'risk class'. The CAPM provides a theory for pricing risk (see generally Reilly, 1989: 281-299).

The CAPM hypotheses the following relationship between return and risk:

$$
r_{i}=r_{f}+\left(r_{m}-r_{f}\right) \beta_{i}
$$

and MMII hypothesizes the following relationship between return and $\mathrm{D} / \mathrm{E}$ :

\section{Table 1 Summary statistics of data}

\begin{tabular}{lcccc}
\hline Variable & Mean & Std.dev & Min. & Max. \\
\hline Ownership & 72.29 & 13.76 & 30.3 & 96.8 \\
D/E & 0.8433 & 2.7316 & 0.00 & 21.79 \\
$r_{2}$ & 16.24 & 9.5913 & -23.63 & 36.56 \\
$\sigma_{r_{2}}$ & 3.086 & 3.9135 & 0.3047 & 25.67 \\
$r_{e}$ & 18.526 & 12.014 & -24.03 & 52.5 \\
$\sigma_{r_{e}}$ & 4.379 & 6.398 & 0.1391 & 34.985 \\
Cash & 353.08 & 680.20 & -193.65 & 5175.75 \\
$\sigma$ Cash & 107.40 & 295.96 & 0.8204 & 1844.344 \\
$\beta$ & 0.7618 & 0.423 & -.3873 & 1.9359 \\
Div.pay & 0.4024 & 0.4989 & -2 & 3.5 \\
$\sigma$ Div.pay & 0.0830 & 0.2182 & .00068 & 1.4855 \\
\hline
\end{tabular}

Table 2 The effect of D/E on performance measures

\begin{tabular}{lcccc}
\hline \multicolumn{4}{l}{ Independent variable $=\mathrm{D} / \mathrm{E}$ ratio } \\
\hline Variable & Intercept & Parameter & P-level & ADJ-R $^{2}$ \\
\hline Mar-ret & 2.05416 & -0.1618 & 0.0280 & 0.0546 \\
$\mathrm{r}_{\mathbf{a}}$ & 17.9233 & -1.9916 & 0.0000 & 0.3118 \\
$\mathrm{r}_{\mathrm{e}}$ & 17.7336 & $\mathbf{0 . 9 3 9 5}$ & 0.0758 & 0.0316 \\
\hline
\end{tabular}




$$
r_{i}=r_{2}+\left[r_{s}-r_{d}\left(l-T_{c}\right)\right] D / E
$$

where:

$r_{i}=$ the expected return on security $i$;

$r_{\mathbf{r}}=$ the risk free rate of return;

$r_{m}=$ the expected return on a market index (the ALSI index was used);

$\beta_{1}=$ measure for the price of risk associated with $i$;

$r_{a}=$ the expected return on the use of assets within the organisation;

$r_{d}=$ the expected return on risk free corporate debt;

$T_{c}=$ the (nominal) corporate tax rate.

The CAPM states that the expected return on an investment in ' $i$ ' is equal to the expected risk free rate plus a premium for risk multiplied by the price of risk $(\beta)$. MMII states that the return on ' $\mathrm{i}$ ' is equal to the expected return on assets plus a premium related to financial risk, scaled up by the $D / E$ rate. Using these expressions, we are able to estimate the risk of the firm's operating cash flows and by implication that risk that is solely associated with financial risk.

By assuming that the risk free rate of the CAPM is equivalent to the risk free rate of corporate debt and that the CAPM is valid, (see Bradfield, 1989; Roll, 1977; and Fama \& French, 1992), it is possible to derive the following expression:

$$
\beta_{1}=\left[1+\left(1-T_{c}\right) D / E\right] \beta_{u}
$$

where:

$\beta_{1}=$ the observed $\beta$ of the levered firm (levered $\beta$ );

$\beta_{u}=$ the derived $\beta$ of the operating cashflows of the firm (unlevered $\beta$ ).

(4) allows us, by using the observed $\beta$, to estimate the unlevered risk of the firm's activities. By definition the levered risk must be higher than the unlevered risk. The difference between the two is a measure of pure financial risk. Given MMII, we expect a positive relationship between this measure of financial risk and the return on the share.

From Table 3, it can be seen that financial risk has no effect on the return on equity, but has a negative effect on return on assets and market returns. Again it appears that MMII is invalidated.

This anomalous discovery calls for explanation. There are two considerations that could account for the anomaly. The poor economic environment of 1991, with its accompanying high interest rates, might account for this finding. In addition, the tax environment of 1991 was largely neutral with regard to debt financing. In that year the marginal tax rate for debt income was $45 \%$ and the nominal corporate tax rate was $50 \%$. There was no tax payable on income received from equity.

Table 3 The effect of financial risk on performance measures

\begin{tabular}{lcccc}
\hline \multicolumn{4}{l}{ Independent variable $=$ financial risk } \\
\hline Variable & Intercept & Parameter & P-level & ${\text { ADJ }-R^{2}}^{2}$ \\
Mar-ret & 2.2002 & -2.2051 & 0.0066 & 0.0902 \\
$r_{\text {a }}$ & 19.0418 & -21.8359 & 0.0000 & 0.3054 \\
$r_{\text {e }}$ & 17.9915 & 4.1707 & 0.4808 & 0.0000 \\
\hline
\end{tabular}

Substituting these figures into $\left\{1-\left[\left(1-T_{c}\right) /\left(1-T_{d}\right)\right]\right\}$ we see that there was a marginal tax advantage to debt financing (0.0909). If we consider that most firms' effective tax rate was less than $50 \%$, we can argue that for these firms and their shareholders there was a tax disadvantage to debt financing. The magnitude of this tax disadvantage could swamp the expected positive relationship.

We now turn to the second avenue of inquiry. Is tight control, within the South African environment, a substitute for debt? In order to gain a proxy for control, the aggregate value of the shares held by the top three major shareholders, as listed by McGregor (1992), was used. Generally, the higher this aggregate, the higher the level of control in the firm. It must be borne in mind that the terms ownership and control are not synonymous in South Africa. Due to the concentrated nature of the economy it is difficult to trace ultimate control within a company. It is for this reason that a proxy for control was used in the analysis. It must be noted that control is a constant (either one has control or not), whereas ownership is variable. To the extent that our proxy is variable, the results of the study may be biased in an unknown direction.

If tight control is a substitute for debt then we might expect, ceteras paribus, a negative relationship between control and $\mathrm{D} / \mathrm{E}$ (i.e., the tighter the control the lower the level of debt within the firm). As the control of the firm becomes less concentrated, managers may take on more debt in order to 'bond' to the shareholders. In terms of our proxy this would imply a negative relationship between the proxy and D/E. In Table 4, we see that the slope coefficient has the correct sign. The relationship however is not statistically significant.

It seems that tight control is not a substitute for debt as a governance structure. We should also investigate the Gerson \& Barr (1992: 22) claim that tight control leads to improved efficiency and, implicitly, superior performance. This was analyzed by regressing the various measures of performance and the control proxy. It seems, from Table 5, that the benefits of tight control are not immediately apparent.

It must be said, however, that Demsetz \& Lehn (1985: 217) argue that there should be no relationship between ownership and (market) profit rates. Their argument is that shareholders would be fully aware of the consequences of diffuse versus light control and that the market would reflect these differences. As such, a cross-sectional study would not capture any

Table 4 Relationship between control and D/E

\begin{tabular}{lcccc}
\hline \multicolumn{4}{l}{ Independent variable $=$ control proxy } \\
\hline Dependant & Intercept & Parameter & P-level & ADJ-R ${ }^{2}$ \\
D/E & 1.6643 & -.0011 & 0.6379 & 0.0000 \\
\hline
\end{tabular}

Table 5 The effect of tight control on performance measures

\begin{tabular}{lcccc}
\hline \multicolumn{4}{l}{ Independent variable $=$ control proxy } \\
\hline Variable & Intercept & Parameter & P-level & ADJ-R \\
Mar-ret & 2.5461 & -.00869 & 0.5605 & 0.0000 \\
$r_{\text {a }}$ & 3.04803 & -.0159 & 0.2180 & 0.0078 \\
$r_{\mathrm{e}}$ & 16.62746 & 0.02626 & 0.8047 & 0.0000 \\
Div.pay & 0.3171676 & 0.001179 & 0.7892 & 0.0000 \\
\hline
\end{tabular}


potential relationship. We should still expect that firms' accounting data should reveal a difference. Demsetz \& Lehn (1985: 218) use accounting data to test for a relationship, but report that the test results are weak. While there is merit in this argument, if the pyramid is unable to demonstrate any superiority, how then does the owner-manager signal his reputation?

We now turn our attention to the issue of 'noise'. The $a$ priori expectation is that the greater the uncertainty in the firm's environment the greater the concentration of ownership there should be. In order to test this hypothesis we regressed the control proxy against various measures of variability (see Table 6).

As can be seen there is no relationship between the control proxy and the variability measures. It is quite possible that the political climate of the 1989-1991 period could account for the lack of significant results. The political and economic uncertainty of the entire period could reduce the test's power to establish any relationship.

The final issue to consider is why investors place their funds on the market, when they know that an agency problem could exist? The answer to this queston lies in the fact that funds within the South African economy are constrained by exchange control. Investors who wish to invest in the market in the absence of a global choice are constrained to invest here. They can and do, however, demand a discount to compensate them for potential agency problems. Kantor (1993: 3) has estimated this discount to be as high as $10 \%$ in the case of Liberty Life's recent listing of Libsil. This has implications for capital budgeting issues. The higher the cost of capital for a firm, the fewer profitable investments are avalaible to it. This implies that the agency problem in South Africa results in less investment and subsequently less employment and slower growth in the economy as a whole.

\section{Conclusion}

We have examined the use of debt by South African organisations. We have been unable to demonstrate that either MMI or MMII is correct. This is entirely counter-intuitive. It is possible that the economic conditions of our test year, 1991, could explain this finding. In that year, firms with high levels of gearing could have found it difficult to survive.

It seems that South African firms do not use debt as a governance structure. This can be seen in the lack of any relationship between $\mathrm{D} / \mathrm{E}$ ratios and our control proxy. This lack of a relationship shows that debt is used purely for financial reasons. We are unable to establish any relationship between the ownership structure and economic variables. It seems reason-

Table 6 Relationship between 'noise' and ownership

\begin{tabular}{lccll}
\hline \multicolumn{4}{l}{ Defendant variable $=$ ownership proxy } \\
\hline Variable & Intercept & Parameter & P-level & ADJ-R $^{2}$ \\
\hline$\sigma r_{\mathrm{a}}$ & 73.60 & -.4250 & 0.3191 & 0.0001 \\
$\sigma_{\mathrm{e}}$ & 72.41 & -.0257 & 0.9219 & 0.0000 \\
$\sigma \mathrm{EPS}$ & 73.20 & -.0142 & 0.1964 & 0.0101 \\
OCash & 73.03 & -.0069 & 0.2202 & 0.0076 \\
ODiv.pay & 72.05 & 2.9719 & 0.6985 & 0.0000 \\
\hline
\end{tabular}

able to conclude that pyramid structures exist in order to facilitate amenity potential. We have, however, not presented any evidence of this conclusion and draw it solely on theoretical grounds.

\section{Note}

The views set our in this article are those of the authors and do not purport to be those of Monitor Company.

\section{References}

Altman, E. 1984. 'A further empirical investigation of the bankruptcy cost question', Journal of Finance, Vol. 39, No. 4: 10671089.

Bradfield, D. 1989. 'A review of capital market theory from a South African perspective', De Ratione, Vol. 3, No. 1: 2-7.

Copeland, T. \& Weston, F. 1988. Financial theory and corporate policy. Third edition. Reading: Addison-Wesley.

Demsetz, H. 1986. 'Corporate control, insider trading and rates of retum', American Economic Review: Papers and Proceedings, Vol. 76, No. 2. Reproduced in: Demsetz, H. 1988. The organisation of economic activity: ownership, control and the firM, pp.223-228. Oxford: Basil Blackwell.

Demsetz, H. \& Lehn, K. 1985. 'The structure of corporate ownership: causes and consequences', Journal of Political Economy, Vol. 93, No. 6. Reproduced in: Demsetz, H. 1988. The organisation of economic activity: ownership, control and the firm, pp. 202222. Oxford: Basil Blackwell.

Denis, D.J. and D.K. Denis. 1994. 'Majority owner-managers and organisational efficiency', Journal of Corporate Finance, Vol. 1, No. 1: 91-118.

Donaldson, G. 1984. Managing corporate wealth: The operation of a comprehensive financial goals system. New York: Praeger.

Fama, E. \& French, K. 1992. 'The cross-section of expected stock returns', Journal of Finance, Vol. 47, No. 2: 427-465.

Gerson, J. 1992. The determinants of corporate ownership and control in South Africa. Unpublished Ph.D Dissertation. Los Angeles: University of California. In Corporate ownership and control in South Africa: Interim Report. University of Cape Town. 1993.

Gerson, J. \& Barr, G. 1992. 'The market as a consultant on equity dilution: corporate control and ownership in South Africa'. In Corporate ownership and control in South Africa: Interim Report. University of Cape Town. 1993.

Jensen, M. 1986. 'Agency costs of free cash flow, corporate finance, and takeovers', American Economic Review: Papers and Proceedings, Vol. 76, No. 2: 323-329.

Jensen, M. 1989. 'Eclipse of the public corporation', Harvard Business Review, September-October: 61-74.

Jensen, M. 1993. 'The modern industrial revolution, exit, and the failure of internal control systenis'. Working paper: Harvard Business School.

Jensen, M. \& Meckling. W. 1976. 'Theory of the firm: managerial behaviour, agency costs and ownership structure', Journal of $\mathrm{Fi}$ nancial Economics, Vol. 3: 305-360.

Kantor, B. 1993. Finding value in unbundling and bundling: $a$ framework for the analysis of acquisitions and disposals. Research Report: Ferguson Bros., Hall, Stewart \& Co. Inc. September.

McGregor, R. 1992. McGregor's quick reference to the JSE. Fifth edition. Johannesburg: Juta.

Miller, M. 1976. 'Debt and taxes', Journal of Finance, Vol. 32, No. 2: 261-275.

Miller, M. 1988. 'The Modigliani-Miller propositions after thirty years'. In Chew, D. (ed.). The new corporate finance: where the ory meets practice, New York: McGraw-Hill, pp.129-141.

Miller, M. 1992. 'Financial innovation: achievements and prospects. 
In Chew, D. (ed.). The new corporate finance: where theory meets practice, New York: McGraw-Hill, pp. 340-347.

Miller, M. \& Modigliani, F. 1961. 'Dividend policy, growth, and the valuation of shares', Journal of Business, Vol. 34, No. 4: 411-433.

Modigliani, F. \& Miller, M. 1958. 'The cost of capital, corporation finance and the theory of investment', American Economic Review, Vol. 48, No. 3: 261-297. In Solomon, E. (ed.). The management of corporate capital. New York: The Free Press.

Modigliani, F. \& Miller, M. 1963. 'Taxes and the cost of capital: a correction', American Economic Review, Vol. 53, No. 3: 433-443.

Myers, S. 1993. 'Still searching for optimal capital structure', Journal of Applied Corporate Finance, Vol. 6, No. I: 4-14.

Reilly, F. 1989. Investment analysis and portfolio management. Fort Worth: Dryden Press.

Roll, R. 1977. 'A critique of the asset pricing theory's tests: Part 1: On past and potential testability of the theory', Joumal of Financial Economics, Vol. 4: 129-176.

Santerre, R. \& Neun, S. 1993. 'Corporate control and performance in the 1930s', Economic Inquin, Vol. 31: 466-480.

Stiglitz, J. 1969. 'A reexamintion of the Modigliani-Miller Theorem', American Economic Review, Vol. 59, No. 5: 784-793.

Stewart, B. \& Glassman, D. 1988. 'The motives and methods of corporate restructuring'. In Chew, D. (ed.). The new corporate $f$ nance: where theory meets practice, pp.584-609. New York: McGraw-Hill.

Warner, J. 1977. 'Bankruptcy costs: some evidence', Journal of Finance, Vol. 32, No. 2: 337-347.

Williamson, 0. 1988. 'Corporate finance and corporate governance', Journal of Finance, Vol. 43, No. 3: 567-591.

Appendix 1: List of companies in sample

ADCOCK

AFCABLE

AMIC

ARGUS
AECI

ALTECH

AMREL

AVI

\begin{tabular}{ll} 
BERZACK & BIDCORP \\
BTRDUN & CADSWEP \\
CARGO & CGSMITH \\
CGSFOOD & CMI \\
CNAGALLO & CONSHU \\
CONFRAM & CONSOL \\
CTP & CULLINAN \\
CURFIN & DELTA \\
EDGARS & EDBRATE \\
ELLERINES & ENGEN \\
EVERITE & FINTECH \\
FSI & GENTYRE \\
GRINAKER & GRINCOR \\
GYPSUM & HAGGIE \\
HIVELD & HUDACO \\
INTERLES & I\&J \\
JDGROUP & KERSAF \\
KNJ & LIONMATCH \\
MALBAK & MEDCLIN \\
METKOR & NAMPAK \\
OK & PEP \\
PERSKOR & PICKNPAY \\
PORTHOLD & REUNERT \\
ROMATEX & SAFCOR \\
SAFREN & SADRUG \\
SENTRACHEM & STANDARD \\
SUNCRUSH & TONGAAT \\
TRANSUN & TML \\
T\&N & UNIHOLD \\
USKO & VEKTRA \\
WALTONS & W\&A \\
\hline &
\end{tabular}

